\title{
THE PRIEST MATIJA MAJAR AND THE MOSCOW ETHNOGRAPHIC EXHIBITION OF 1867
}

\section{BOŽIDAR JEZERNIK}

The author discusses the meaning and role of the AllRussian Ethnographic Exhibition and Slavic Congress beld in Moscow in 1867 and Matija Majar's donation of six folk costumes from the Zilja-Gail Valley in Carinthia to the organizers of the exhibition. The author explains how the imperial powers used exhibitions to send the message that progress and civilization could only occur within the colonial enterprise. For them, the motto of exhibitions was: scholarship is proof of our superiority. For smaller nations, especially for "awakening" ones, taking part in an international exhibition was a convenient opportunity to establish themselves as nations, and their motto was: scholarship is proof of our ethnic individuality.

Keywords: ethnographic exhibition, Moscow, Matija Majar, ethnography, Panslavism
Avtor predstavi pomen Etnografske razstave in Slovanskega kongresa $v$ Moskvi leta 1867, pri čemer se posebej posveti ljudskim nošam iz Ziljske doline na Koroskem, ki jih je Matija Majar podaril organizacijskemu odboru. V prispevku pojasni, kako je Rusija izrabila prireditev za prikaz narodnega napredka in civiliziranosti, ki najdeta svoje mesto le $v$ imperialnem kontekstu. S tega vidika je bilo torej osrednje sporočilo razstave: znanost dokazuje našo superiornost. Manjšim narodom, ki so v tistem ćasu doživljali "prebujenje", pa je sodelovanje na prireditvi pomenilo priložnost, da se vzpostavijo kot narodi. Njihov moto je zato bil: znanost dokazuje našo etnično samobitnost. Ključne besede: etnografska razstava, Moskva, Matija Majar, etnografija, panslavizem

\section{THE WORLD-AS-EXHIBITION}

During the nineteenth century, one of the most popular means of interpreting reality was exhibitions. They offered visitors opportunities to become acquainted with the latest works of art and to assess their ability to compete (see, e.g., Bleiweis 1844: 162163). U.S. President William McKinley made explicit the connection between fairs and progress: "Expositions are the timekeepers of progress. They record the world's advancement. They stimulate the energy, enterprise, and intellect of the people and quicken human genius" (cited in Rydell 1984: 4). Hence, in the mid-nineteenth century in the great European colonial metropolis a new age had begun, which Timothy Mitchell called the "world-as-exhibition" (Mitchell 1988: 13).

Anthropology also played a role in the world-as-exhibition. In the context of late nineteenth-century imperialism, Tony Bennett (1995: 77) argues that it was the employment of anthropology within the exhibition complex that proved most central to its ideological functioning because it played the crucial role of connecting the histories of Western nations and civilizations to those of other peoples. 
By and large, this was achieved by the representation of "primitive peoples" as instances of arrested development, as examples of an earlier stage of species development which Western civilizations had long ago surpassed. Indeed, such peoples were typically represented as the still-living examples of the earliest stage in human development, the point of transition between nature and culture, between ape and man, the missing link necessary to account for the transition between animal and human history. Denied any history of their own, it was the fate of "primitive peoples" to be dropped out of the bottom of human history in order that they might serve, representationally, as its support-underlining the rhetoric of progress by serving as its counterpoints, representing the point at which human history emerges from nature but has not yet properly begun its course. (Bennett 1995: 78-79)

As Paul Greenhalgh suggests in his study on great exhibitions and world's fairs, international exhibitions slowly evolved as a cultural phenomenon for almost a century before the first event identifiable as an international exhibition actually took place at the Crystal Palace in London in 1851. Through this preliminary period, in tandem with the unfolding of the industrial revolution, institutions formed in France and Britain with the specific aim of promoting the principle of display. In the first instance, this was to be a device for enhancing trade, for promoting new technology, for educating the middle classes, and for elaborating a political stance (Greenhalgh 1988: 3). Greenhalgh identified a dual aim in the reasoning behind the imperial displays at the Great Exhibition:

The grandeur of the material wealth of British possessions was to be made clear; and the necessarily alien nature of the empire was to be reduced and the whole melted into the average British consciousness. The exhibition was to simultaneously glorify and domesticate empire. (Greenhalgh 1988: 54)

The Crystal Palace became a symbol that earned comment and emulation around the world, and before long other nations began planning their own exhibitions along similar lines. On 14 May 1864, the Society of Friends of Natural History (Obshchestvo Lyubiteley Estestvoznaviya) of Moscow University was established (Komitet vystavki 1867: 2). Its members resolved to sponsor an all-Russian anthropological-ethnographical exhibition. The zoologist Anatoly Petrovich Bogdanov had conceived the idea in 1859 , viewing the Crystal Palace at Sydenham, to which the exhibition had been transported after the original event closed in 1851. Bogdanov was attracted by ethnological displays encompassing the entire non-European world. Mannequins representing indigenous inhabitants were depicted in the midst of native flora and fauna together with the characteristic accoutrements of their everyday life (Komitet vystavki 1867: 5). According to Nathaniel Knight, two points in particular motivated Bogdanov: 
First, was the total absence of the peoples of the Russian Empire, many of whom were easily as primitive and exotic as the natives on display in the Crystal Palace. Including these peoples within the general framework of the Sydenham exhibition could only enhance its value from the point of view of science. Second, was the fact that nothing like the Sydenham exhibition had ever been produced on Russian soil. A similar exhibit in Russia, displaying the numerous peoples of the Russian Empire alongside the exotic denizens of Sydenham, would almost certainly elicit great interest and would serve as a powerful tool for the popularization of science. (Knight 2001: 5-6)

At the end of 1864, Bogdanov submitted his proposal for an exhibition to the society. Because the public was more familiar with the main features of African and Australian tribes than those inhabiting the Russian Empire, he argued, there was no aspect of natural science as deserving as anthropology of the efforts of the Society of Friends of Natural History for the dissemination of information among the general public (Komitet vystavki 1867: 2-3). Bogdanov's vision of displaying the full range of the global diversity of the human races, however, was not realized. Instead, the organizers decided to exhibit the peoples living in the Russian Empire. Thus, although the peoples portrayed in the displays might be wild and exotic "others," they remained Russia's others, internal aliens whose character and lifestyles constituted part of the overall might and diversity of the empire. In one respect, however, the exhibition followed Bogdanov's original anthropological focus; namely, the basic assumption that the groups on display could be identified as distinctive through their physical features. It was therefore essential that the mannequins put on display portray the distinctive features that characterized each unique "national type" (Knight 2001: 13).

\section{THE SLAVIC SECTION}

It was not until late in 1865 that any Panslavic theme was introduced into the plans. Nil Aleksandrovich Popov had made an extensive tour of the Slavic lands of eastern Europe in 1863 and 1864 . He had come to the conclusion that it would be desirable to see objects having to do with Slavic ethnography in general at the exhibition; first, because the Slavs should serve as a term of comparison in the study of Russian nationality, and, second, because among the West Slavs the Poles lived within Russia itself, and among the South Slavs there were the Serbs and the Bulgarians. In late 1865, he proposed that in addition to the Russian section an additional Slavic section be included comprising the Slavic peoples living in the Austrian and Ottoman Empires (N. Z. 1867: 177; Komitet vystavki 1867: 21-24). The organizing committee also decided 
to add the Slavic section to the exhibition in order to represent an image of "all Slavic tribes as an ethnographic whole" (Matković 1867: 192).

The change of the original plan for the exhibition was motivated more by political reasons than scholarly ones. As Mikhail Nikiforovich Katkov wrote in Moskovskiya on 7 April 1867: "If France supports the unification of Italy, and Prussia the unification of Germany, Russia has the same obligation towards the Slavs and it is obliged to fulfill it" (cited in Klaczko 1867: 14).

As his proposal was accepted, Popov began to issue invitations to various Slavic organizations and scholars abroad. Popov's most active assistant proved to be Protoiereus Mikhail Raevsky, dean of the Russian Embassy church in Vienna and an ardent Slavophile, who had cultivated the friendship of many prominent Austrian Slavs during his many years of service in the Habsburg capital. Raevsky had published an informative handbook in German entitled Die Russische Ethnographische Ausstellung in Moskau (The Russian Ethnographic Exhibition in Moscow; Vienna, 1866) for distribution among the Austrian Slavs. It contained guidelines for participants with instructions about the collection of ethnographic objects. In Ljubljana, Raevsky contacted Lovro Toman and Janez Bleiweis, the leading figures at the Slovenska Matica (Slovenian Society), and his call for contributions was published in full in Novice gospodarske, obrtniške in narodne (Anon. 1866a: 239-240, 256-257, 305-306; see also Karpova 1975: 44; Petrović 1989: 40-41).

In his letters to Popov, in May and June 1866 Raevsky reported that he had contacted the Slovenska Matica, lamenting that he could not get anything from the Slovenians. However, in October 1866 he happily reported to Moscow: "The Slovenians are sending us a Carniolan wedding ${ }^{1}$ with all that goes with it, only without a horse and a cart” (Čurkina 1974: 61). As stated by Jurij Fikfak, whereas other contributors presented individual costumes, Majar strove to show their function and reconstructed the image of a ritual practice, in which the costumes were "an important and active factor demarcating national identity" (Fikfak 2008: 41). Majar's contribution was described in detail in Slovenski Glasnik:

It is known to all the Slovenians that in the next month a great ethnographic exhibition in Moscow begins; with these lines I am announcing to them that our valley, which has up till now, as the only one in Carinthia, completely kept its old garb and many other customs from days of yore, will also be represented. Praise for this goes to the renowned patriot Matija Majar, who procured with stiff expenses what is needed so that a man and woman from the Zilja/Gail Valley will proudly be put on show to visitors to the great Slavic exhibition. For the purpose he bought diverse clothes, tailored according to the old customs, as are still worn by

Raevsky was incorrect. This was a Carinthian wedding. 
old natives of the Ziljal Gail Valley; here you can see, for instance, a red coat stretching to the ankles, green breeches, and so on. Even more pleasing to the eyes are the costumes of the bride, bridesmaid, groom, wedding guests, elders, and others, as is still the habit. Furthermore, he had chests and cases made for the bride, a bed, and so on; nothing is missing of what a bride needs in her new home, such as a spinning wheel, and so on. In addition, images were also provided, copied from photographs of the bride and the groom on a horse, of the wedding guests, and other distinguished persons at the wedding party. All this, as we heard, the renowned patriot has already sent to Vienna, whence it will go on a pilgrimage to illustrious Moscow. (K. M. 1867: 95)

As noted by Peter Nesý in his memoirs on Matija Majar, the value of the objects was estimated at 400 gulden; a huge sum if one takes into account that from 1867 to 1870 Majar's annual salary was 315 gulden (Čurkina 1974: 57, 61).

In appreciation of his donation, Majar was invited to the Moscow ethnographic exhibition. It is noteworthy that out of ten Slovenians that received an invitation to the exhibition (Bleiweis, Toman, Einspieler, Janežič, Trstenjak, Razlag, Costa, etc.), only Majar had enough pluck to accept it (Čurkina 1974: 61). Janez Bleiweis wrote on 8 February in a letter to Raevsky that he, Etbin Costa, and Lovro Toman were "unfortunately" unable to travel to Moscow (Karasev et al. 1975: 45). Based on Majar's account, Nesý represented the story of his travel as follows:

He wavered. Bishop Vieri, an Italian, when he learned that Majar had been invited and believing that he would really go, said to a certain priest that Majar hitherto had not asked for leave and that he would not give it to him at all, if he had. However, if he went to Russia without permission, then applications for his post should be invited and taken up at once. A friend informed Majar about the bishop's design. Although until then he had not had the intention to travel to Moscow, he was now so enraged that he set out on his journey without much preparation. (cited in Čurkina 1974: 58)

The rich acquisition of wedding costumes and all the accessories encouraged the organizers of the Ethnographic Exhibition to present a complete genre scene of a Slovenian wedding ritual, represented with wax figures. In order to create them as authentically as possible, they needed photographs and drawings of characteristic Slovenian figures from the Gail Valley. Majar sent twelve photographs and drawings of six Slovenians (four men and two women) to Moscow to serve as models for the exhibition. Majar also sent the organizing committee a written description of the group (Čurkina 1974: 57). 


\section{THE PILGRIMAGE}

The Ethnographic Exhibition in Moscow coincided with the Austro-Hungarian Compromise, which was in actual fact an arrangement enabling the two leading nations to divide the proceeds of oppression in the monarchy between them. What lay in store for the Austrian Slavs was made graphically clear in the dictum attributed to Chancellor Friedrich Ferdinand Beust: "Man muss die Slawen an die Mauer drücken" (The Slavs must be pressed against the wall; Komitet vystavki 1867: 370; Clementis 1943: 47-48; Petrovich 1956: 203-204). The establishment of the Dual Monarchy provoked a strong protest from the Slavic citizens of the monarchy. As a result, sending ethnographic objects to the Moscow exhibition acquired the character of a political demonstration. František Palacký, the famed Czech historian and politician, warned: "The day Dualism is proclaimed will, by an invincible necessity, likewise be the day when Panslavism will be born in its least desirable form" (cited in Prelog 1931: 35; see also Klaczko 1867: 31; Kazbunda 1924: 37).

Within this context, representatives of all Slavic peoples from the Austrian and Ottoman Empires were invited to Moscow. The majority of the delegates from South and West Slavic countries gathered first in Vienna (Slovenec cestujuči 1867: 171) where, on 3 May 1867, they boarded the train to the "Panslavic Mecca," as the German press phrased it (see, e.g., Anon. 1867a: 1; Anon. 1867c: 2.).

Altogether, eighty-one Slavic representatives from abroad attended the exhibition and congress. Among them were twenty-six Czechs, sixteen Serbs, ten Croats, four Ukrainians, three Slovaks, and three Slovenians: the Catholic priest Matija Majar, merchant Ivan Vilhar, and clerk Aleksander Hudec (Polit-Desančić 1883: 69; Prijatelj 1939: IV, 105; Nikitin 1960: 175; Karasev et al. 1975: 45). ${ }^{2}$ As noted by Die Debatte, Slovenian deputies Janez Bleiweis, Etbin Costa, and Lovro Toman had not accepted the invitation to the ethnographic exhibition in Moscow, although all their expenses would have been covered (Anon. 1867b: 2).

Matija Majar described his journey in his written application, when he had to defend himself on account of visiting the exhibition:

The University of Moscow invited me together with other Slavic men of letters, learned men, and private persons from Austria, Turkey, Prussia, and Saxony, to visit the ethnographic exhibition. That this honor had befallen on me, an unknown and simple Carinthian priest, happened as follows: In 1863 and 1864, I published a comparative grammar of Slavic dialects and the booklet The Saintly Brothers Cyril and Methodius. . . . Thus, my name became famous, which was unknown to me, within the most distant Slavic circles. I also sent wedding costumes for

2 According to the report in Die Debatte, on 4 May 1867, these were Ivan Vilhar and a certain Gubec from Ljubljana, and Matija Majar from Klagenfurt (Anon. 1867f: 2). 
six people to the exhibition; on account of this, they invited me personally to visit it.

I wanted to see the exhibition, as do those who travel to exhibitions in Paris or London. The Ethnographic Exhibition was very interesting and instructive. Statues with diverse costumes of Slavic peoples and other peoples living in Russia were displayed. One would have to traverse half of Europe and a third of Asia to see what you saw here put together in one building. Like any traveler, I wished to see foreign places, lands, towns, and people of such distant lands where but rarely does there appears a simple Carinthian like me.-I considered it a great honor that I could travel in the company of such learned men, for there was the cream of Slavic intelligentsia.... I also travelled for material reasons. Namely, like for all the other travelers, in Russia my first-class railway journey was paid for, and in Saint Petersburg and in Moscow we had free accommodation and service. It wouldn't have been possible for me to travel at my own cost; I set off because I had been personally invited and the journey did not cost me too much. (-ž-. 1893: 201-202)

All the way from the Russian border to Moscow was "a real fête," "marked by an unending series of banquets, both public and private, attended by passionate oratory in which the Russians and their guests declaimed on their love for one another" (Petrovich 1956: 208). Masses of people greeted "the pilgrims" with music and flags, offering Slavic guests bread and salt (see, e.g., Sk. Kh. 1867: 186-187; Anon. 1867h: 4; Majciger, Pleteršnik, and Raić 1873: 1367; -ž-. 1893: 202).

During their journey and their stay in Russia, the delegates were welcomed by prominent public officials. They enjoyed lavish hospitality from the wealthy noblemen and merchants, as well as from many different segments of Russian society. Emperor Alexander II, known as "the Liberator," welcomed them at the festive reception in his residence at Tsarskoe Selo, greeting "Slavic brethren on native Slavic soil" (Komitet vystavki 1867: 232; Sk. Kh. 1867: 186-187; V. V. 1867: vii; Vošnjak 1905: 247; Prelog 1931: 80; Petrovich 1956: 209, 220; Fadner 1962: 261, 266; MilojkovićDjurić 1994: 80).

In Saint Petersburg several thousand well-wishers greeted them, and in Moscow even more of them (Polit-Desančić 1883: 71-74; Mijatovich 1885: 23). According to Majar, the reception at the Russian border was "most beauteous, cordial, brotherly; and the journey to Saint Petersburg and to Moscow was a triumphal march (Triumphzug); life during these five weeks was such as though we were changed by magic art into most illustrious magnates, as though we were living in the loveliness of a magic native world; moreover, this was no magic, no sorcery (Zauber), but the real plain truth" (Majar 1873: 97). 
However, during their journey the Slavic visitors to the exhibition did not have many opportunities to make contacts with the Poles. According to some reports, the Poles in Warsaw were angry with them (Mijatovich 1885: 24; Prelog 1931: 72). According to Julian Klaczko, it was only after Vilnius and the Grand Principality of Lithuania that the receptions and ovations began to obtain a spontaneous and universal character (Klaczko 1867: 45).

The Polish representatives declined the invitation to participate in the Ethnographic Exhibition and Slavic Congress in Moscow and, with the aid of the pro-Polish and progressive Czechs, tried to induce the Czechs to follow their example. The Polish press in the Austrian Empire and the German Empire also took the opportunity to engage in a virulent campaign against "the Slavic Peril" and Russia's imperialistic designs (Komitet vystavki 1867: 99-101; Mijatovich 1885: 23; Prelog 1931: 38; Tobolka 1933: 153; Clementis 1943: 47; Petrovich 1956: 20; Tanty 1970: 134). Palacký and Rieger went to Russia by way of Paris, where they called on two prominent Poles, Prince Władisław Czartoryski and Count Andrzej Zamoyski, for the purpose of discussing with them the possibilities of mediation between the Russians and Poles. They had no success with the Poles, and in Moscow they had no success with the Russians either (Komitet vystavki 1867: 103-104; Klaczko 1867: 17; Clementis 1943: 48). Russian Panslavists spoke about the Poles as a foreign body within Slavdom, mainly due to Polish Catholicism (see, e.g., Tanty 1970: 135, 140).

The German press in Austria shared the opinion that the Moscow exhibition was not just an exhibition, but a political declaration. As the Laibacher Zeitung wrote on 10 May 1867, quoting the Polish Gazeta Narodowa from Lviv: "The Ethnographic Exhibition in Moscow is the first beginning of Muscovite annexation in the name of the Slavic idea" (Anon. 1867g: 1). The Viennese Die Debatte deemed the participation of the Austrian Slavs at the ethnographic exhibition in Moscow to be an "anti-Austrian demonstration" (Anon. 1867i: 1).

The Hungarian press was even more agitated, introducing military rhetoric into the discourse about an ethnographic exhibition. Thus, Pesti Napló, reporting that there were some people in Hungary that wished to visit Saint Petersburg and Moscow in order to meet Alexander Hilferding, Ivan Aksakov, Ivan Turgenev, and Vladimir Lamansky, promised that the Hungarians would be the bulwark of Europe against assaults of Slavic "barbarism" (Komitet vystavki 1867: 101).

Not only the leading newspapers in Vienna and Pest, but also provincial ones joined the choir disclaiming the wishes of Slavic representatives to attend the Ethnographic Exhibition in Moscow. The Novice in Ljubljana, for instance, reported:

At the exhibition in Moscow, Slovenian costumes will also be represented: from the vicinity of Ljubljana (a boy and a girl in beautiful folk dress from top to toe), from the Zilja/Gail Valley (groom, bride, etc.), and, as far as we know now, also going will be the famous writer 
Matija Majar, Ivan Vilhar, and Aleksander Hudec. In the Saturday issue of Laibach. [Laibacher Zeitung] "Feuilletonist" preposterously makes a mockery of the Moscow exhibition, although he himself says (if he was not lying) that he knows nothing about it but what "the Russian and Croatian newspapers informed him. "If Novice had described a "Turner-Schützen"-or "Sängerfest" out there in "the Reich" in its papers in such length as they described the ethnographic exhibition in Moscow in last year's papers no. 30, 32, 38, 39, and 42, "Feuilletonist" would surely have read them assiduously and bought them for his newspaper; yet what sort of "original-notice"? But he shivers at the Russian exhibition, and therefore he would rather not read it. The German and Hungarian newspapers in particular began to yell in an ugly manner on account of this exhibition, as if they were afraid, perhaps, that their conscience was troubling them. Some newspapers, such as Presse and Debatte, are even raging! And why? - for this reason, because, as European states continuously organize exhibitions, the mighty Russian state is also for once organizing an exhibition, and indeed a very interesting, instructive, ethnographic exhibition, and because these important exhibits are also going to be seen by the Austrian Slavs, for whom-in accordance with traditionally renowned Slavic hospitality-a cordial brotherly reception is being arranged. And the fact that the Slavs are going to visit an exhibition on Slavic territory - that they are traveling to the state whose ruler stifled a Hungarian rebellion in 1849 and helped Austria save itself from ruin-this is fire in the roof of those Austrian Germans that were visiting the assemblies of the German $\mathrm{Na}$ tionalverein, the German Abgeordnetentag, the German Ausschussin general, all the assemblies of the German political societies that are constructing Greater Germany! - this is the fire in the roof for those Austrian Germans that in 1848 in Frankfurt manifestly sermonized "the end of Austria." We still have the page from Allg. Zeitg. that carries Giskra's speech from 1848: "Ein einiges Deutschland! und sollten alle Diademe darüber erbleichen und alle Throne stürzen" (donnernder Beifallssturm), —and Wiesner's speech: "Dass die Čehen, Kroaten und die übrigen Südslaven den österreichischen Gesammtstaat erhalten wollen, begreifen wir sehr gut, denn die Slawen würden beim Fortbestehen desselben unfehlbar das Heft in die Hand bekommen."-Do you think that we, the South Slavs, have forgotten all that? Do you think that we do not know why the Hungarian Debatte and the Greater German Presse now whack the Austrian Slavs in such an ugly manner, as if they were going to Russia to betray their emperor or to devise a plot! The 
Austrian Slavs know very well what the aims are of some German and Hungarian journalists, and if there is to come-God forbid!-yet another year like 1848, you will see where the Slavs will stand, and where the Germans and Hungarians! - From the Czech lands Palacky, Rieger, Brauner, Baron Vilani, Erben, and Hamernik are going to Moscow; among them, then, precisely the man whose famous saying is "that Austrian Slavs would have created Austria if it had not already existed." (Anon. 1867e: 149-150)

As suggested by Michael Boro Petrovich, "the hostile press campaign did much to transform the rather nebulous Panslavic movement into one of the most discussed and least understood bogeys of European politics” (Petrovich 1956: 238). Kollár's foggy idea about Slavic mutuality in the journey to Russia in 1867 "changed from a chimera into a political reality or a real political argument” (Hlavačka 2006: 53).

Within the context of a political crisis, the suggestion of impending Slavic unification led by Russia appeared, from the Austro-Hungarian perspective, to be a threatening provocation. Newspapers in Austria-Hungary voiced demands for prosecution of the "pilgrims." Chancellor Beust did not support their penalization, but he registered the "pilgrimage" of the Czechs in the book of sins, which he leafed through with greatest pleasure when it was necessary to reproach Czech politicians with something (Komitet vystavki 1867: 100; Kazbunda 1924: 77-79; Prelog 1931: 121). The same language as in the German newspapers was chosen by the Polish press in the Austrian Empire and the German Empire condemning "pious pilgrims, who beneath the Carpathian and the Balkan Mountains in mid-May journeyed to pay homage to the 'Slavic Mecca"' (Klaczko 1867: 30).

In Austria, the exhibition continued to echo in 1868. When Josip Vošnjak, for instance, spoke about Slavic loyalty in the Styrian Assembly and how Austria owed it to the Slavs that it had not disintegrated in 1848, the deputy Karl Rechbauer heckled him, saying "Moscow." Vošnjak responded with the explanation: "I did not go to Moscow (laughter), and there was just a scholarly exhibition, an ethnographic one. (Greater laughter.) We, the Slavs, had not articulated such unpatriotic threats, and, if somebody had done this, he would surely be serving his time in prison in Kufstein" (Vošnjak 1868: 2; cf. also Vošnjak 1905: 248).

Some of Austria's Slavic subjects were to pay dearly for taking part in this event. The Austrian Serb Mihailo Polit-Desančić was deprived of the right to practice law. His colleague Jovan Subotić lost his position in the Croatian courts and was denied a pension because he had gone to Russia. The bishop of Klagenfurt forced the Slovenian Roman Catholic priest Matija Majar to pay a fine of twenty-five gulden because he left his parish without higher permission (Komitet vystavki 1867: 470; Polit-Desančić 1883: 80; Vošnjak 1905: 248; Prelog 1931: 47, 124-125, 128; Petrovich 1956: 238-239; Čurkina 1974: 61-62). 


\section{THE ETHNOGRAPHIC EXHIBITION}

The Ethnographic Exhibition was ceremonially opened on 23 April 1867 by His Imperial Highness the Grand Duke Vladimir Aleksandrovich, the honorary chairman of the exhibition. The grand duke was present at the Te Deum, which was sung in honor of the occasion, and listened to the stirring speech by Protoiereus Sergievski, who reminded the assembly of the solemnity of the event and the significance of the presence of so many non-Russian Slavs whose arrival at Moscow would certainly make the Russians more keenly aware of the reality of racial brotherhood. He reminded his audience of the non-political character of the forthcoming congress, which on the next day was visited by the tsar and tsarina (Komitet vystavki 1867: 30; Prelog 1931: 68; Fadner 1962: 259).

As noted by a Polish critic of the exhibition, political symbolism played an important role in mapping the topography of the exhibited universe: in the midst of a huge exhibition hall, the imperial lodge was raised as "a symbolic central point of Slavdom spreading up around it" (Klaczko 1867: 20). The group of wax figures representing the Russians numbered seventy-three mannequins from sixteen different governorates meticulously rendered "with greatest care" (Matković 1867: 202).

One hundred sixteen mannequins were put on display at the exhibition, dressed in folk costumes of the non-Slavic peoples of Russia, 118 mannequins representing ethnic types of East Slavic peoples, and sixty-six mannequins representing West and South Slavic peoples (Čurkina 1974: 59, 61). For three months, Moscow’s main exhibition hall, the Manege, had its doors open to the All-Russian Ethnographic Exhibition. The exhibition comprised three sections: the first section comprised groups representing diverse tribes living in Russia and other Slavic lands: 1. Non-Slavic tribes, and 2. Slavic tribes, divided into two groups: a) the East Slavs and b) the West and South Slavs; the second section was dedicated to general ethnography, and the third to anthropology (Matković 1867: 194).

Realistic details should have helped to ensure the "authenticity" of the images displayed. The peoples on display were represented by life-size mannequins dressed in typical costumes. The heads of the mannequins authentically represented the peoples highlighted, and the organizer paid full attention to the details regarding their complexion and natural type. In addition, alongside every group of people on display were characteristic flora and fauna of their native surroundings (Matković 1867: 210). Thus, for instance, close by the imperial lodge there was a decoration representing pine and fir woods with a belfry of a village church, a windmill, some ten to twenty peasant cottages, and a fair. A group of Russians was there with many different "types": a blacksmith "with athletic hands," a bear-tamer "with a frightful four-footed beast," and Gypsy women; they were "so alive and typical" that some visitors felt ready to give them alms (Klaczko 1867: 21). 
The groups on display were exhibited in such a way that the visitors could observe "a vivid ethnographic map of Russia and the whole of Slavdom" (Matković 1867: 194). Each wax figure was described in detail, and every piece of clothing and every ethnographic object precisely labeled. Brief information on every tribe at the exhibition represented in pictures was given, describing the geographical area these people occupied, its physical characteristics, the state of culture, and the size of the population and its conditions. These explanations, however, did not have any scholarly value because for the Russian peoples they were taken from Pauli's Russian ethnography, to which Colonel Roderich von Erckert added his descriptions. Regarding the other Slavs, information was extracted from well-known ethnographic works by Pavel Jozef Šafárik, Karl von Czoernig-Czernhausen, Guillaume Lejean, and so on (Matković 1867: 193).

Novice gospodarske, obrtniške in narodne notified its readers about the exhibition in a detailed report contributed by a Slovenian visitor:

The peoples were presented in groups; the greatest one being the group of the Great Russians. Here, the inhabitants of Great Russia are seen at a fair. There stand some sixty people in a village on the road in various positions. To the left of the village is a windmill. On the left side of the company at the fair is a man selling icons, on his right side there stands an unharnessed horse, eating hay from a peasant cart. In front is a small shop (or hut) in which they are selling mead, and around which everything is swarming with vendors and buyers. On the left there is a bear-tamer with two bears. Behind them there is a man selling kvas and baked plums, beside this traveling salesmen are offering goods on sale, and fur caps embroidered with gold and cloth. The figures are variously dressed, and women from the land of Tver in particular distinguish themselves with curious costumes that are lavishly trimmed with gold. Between the tsar's lodge and the fair square there stand the Great Russian buildings with all conveniences. Here is a well on scales with a wheel, a weaving-loom, a new cart, and a pot for washing with two funnels hanging on the rooftree. Beside one house is a vegetable garden, in the court a heap of hay, a wheelwright's workshop woven from reeds, two house guardians (a dog and a cock), and a mother cradling her child in a sieve. In the house a big stove is to be seen, along the walls robust benches, and on the four-cornered table there is a large wooden salt-cellar, deep circular bowls, and in the corner opposite the doors a small wardrobe with images of the saints in front of which a light is usually burning.

A Little Russian [Ukrainian] clay thatched house can also be seen, around which a clay bench is made. On the top of the roof there stands 
a stork. Beside the house there is an orchard where sunflowers grow, the seeds of which the peasants are fond of eating, pumpkins, and many other things. Beside the furniture a yoke of Podolia oxen is lying in front of a peasant cart. The faces of the Little Russians are not like those of the Great Russians; they all wear moustaches only.

Of the West Slavs, the Poles with long blue coats with red trimmings first catch the eyes. The costumes of the other West Slavs remind one much of costumes of the peoples with whom they live or border.

Of the non-Slavic inhabitants of Russia, there are especially many people that dwell in huts on the steppes. A whole row of Kyrgyz and Bashkir felt tents can also be seen. The essential part of household furnishings are rugs, seats resembling sofas; in the middle of the tent an iron kettle, leather jugs, and large skins. Siberian Kyrgyz women wear tower-like, two-foot-tall velour caps embellished with gold and gems. The caps of the Kyrgyz women of Orenburg are lower, but with more gems in them. A camel and a horse, livestock of the Kyrgyz and Kalmyk peoples, are placed near the tent.

From the Caucasus there is little to be seen. Of other peoples of special interest are the Mingrelians and Gurians, the Sarts, the inhabitants of Tashkent with white turbans, the Kolosh [Tlingit] people from Russian North America with blackened faces, the Buryats in the Chinese custom, the Tatars from Kazan, the Yakuts and Tungus [Evenks] with reindeer and a birch-bark tent, the Samoyeds with sleds and reindeer hides. At the distant end of the building one can also see a very interesting group. Seven tall, lean persons that are but modestly covered with silky clothes are standing and sitting around a fire, steaming from the floor. They are Zoroastrians and are praying to the fire.

Among the tools displayed two fishing boats from the land of the Mohils [sic] are also of particular interest; they are cut out of one trunk and fastened together with a wedge.

As for the exhibition in general, everybody has to become cognizant that the artists and learned men copied it faithfully after details from life, for nowhere can one notice a face or image that is invented. The exhibition could not possibly be better composed, and for this reason it is highly instructive. (N. Z. 1867: 185-186)

Representing the peoples and their way of living is an expression and a source of power (Bond and Gilliam 1994: 1), hence it is always closely connected with political processes and, above all, with the question of who makes decisions as to who can represent whom, how, where, and with what. Thus, the organizers pursuing their ends decided 
to avoid the use of the Polish name when representing West Slavs, replacing it with less "pretentious" ones that gave a better pretext for the regime of divide and rule, such as the Masurians, the Krakowiaks, the Podlesians, the Lithuanians, the Samogitians, and so on (Klaczko 1867: 22). On the other hand, when representing the "primitive" peoples, such as the Yakuts or the Samoyeds (Nenets), they chose to represent them in their natural surroundings, providing a "scientific" basis for the image of the non-European world as barbaric. The group of Yakuts, for instance, was presented at the shamanic rite, in which a shaman "of horrible sight," with drums in his hands, during the worship surrounded with signs of his role, was uttering "a terrible conjuration" (Klaczko 1867: 23; Matković 1867: 195). The Nenets, however, were represented making a sacrifice: the priest proclaims augury with the help of drums, and in the meantime one of his helpers is putting the rope around the neck of his sacrificial victim, and the other, with a knife in his hand, is getting ready to cut the victim's throat (Klaczko 1867: 24; Matković 1867: 196).

For the organizers, displaying the peoples of the Russian Empire with all their characteristic features created an ideological imperative to stress what was, for the ethnic Russians, the most characteristic feature of all: their superiority with regard to the empire as a whole. The introduction of Slavic peoples created another imperative to show the position of the Russians as the most powerful, most viable members of the Slavic family, and hence the nucleus around which Slavic unification would take place. However, as Knight ascertained, it was precisely the theme of Russian ethnic superiority that the ethnographic display as a medium of representation was least able to convey (Knight 2001: 28).

For the Moscow intellectuals that were the driving force behind the event, a view of the exhibition solely as a display of the population of the Russian Empire was not entirely satisfying. Merely presenting the empire as a conglomeration of diverse peoples ruled over by the tsar left unresolved the role and status of the Russian people itself. Was the Russian nation really just one individual piece in the vast ethnic mosaic of the empire? Sergey Maksimov, for instance, opposed such a view. The Russian people, he argued, was the "single force" that was able to "organize a state and rule over such a multitude of ethnically diverse peoples" (cited in Knight 2001: 15).

As argued by Knight, the difficulties in visually expressing the idea of Russian preeminence stemmed from the scholarly framework in which the exhibition was presented. The organizers wanted to show Russian superiority, but were constrained by limited means of expression and the imperative of authenticity. In the case of the Russians, it was "natural" that the organizers turned to the groups that had most completely preserved the essential features of ethnic distinctiveness: the peasantry and the urban lower classes. "But these were precisely the groups that manifested least of all any kind of innate superiority over their Slavic and 'alien' neighbors" (Knight 2001:21). 


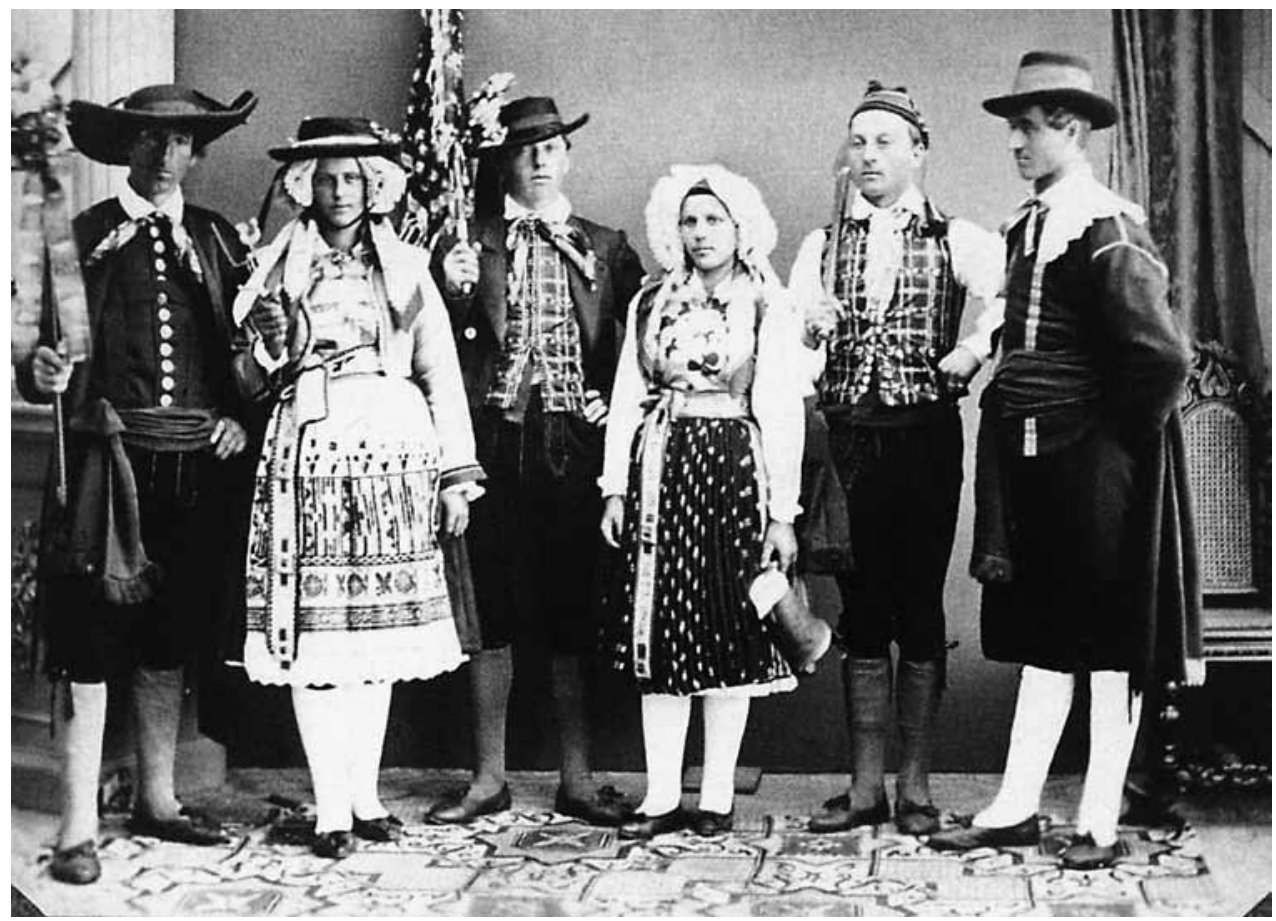

A group of Zilja/Gail Valley residents wearing costumes sent by Matija Majar to Moscow, photograph made in a Beljak/Villach studio.*

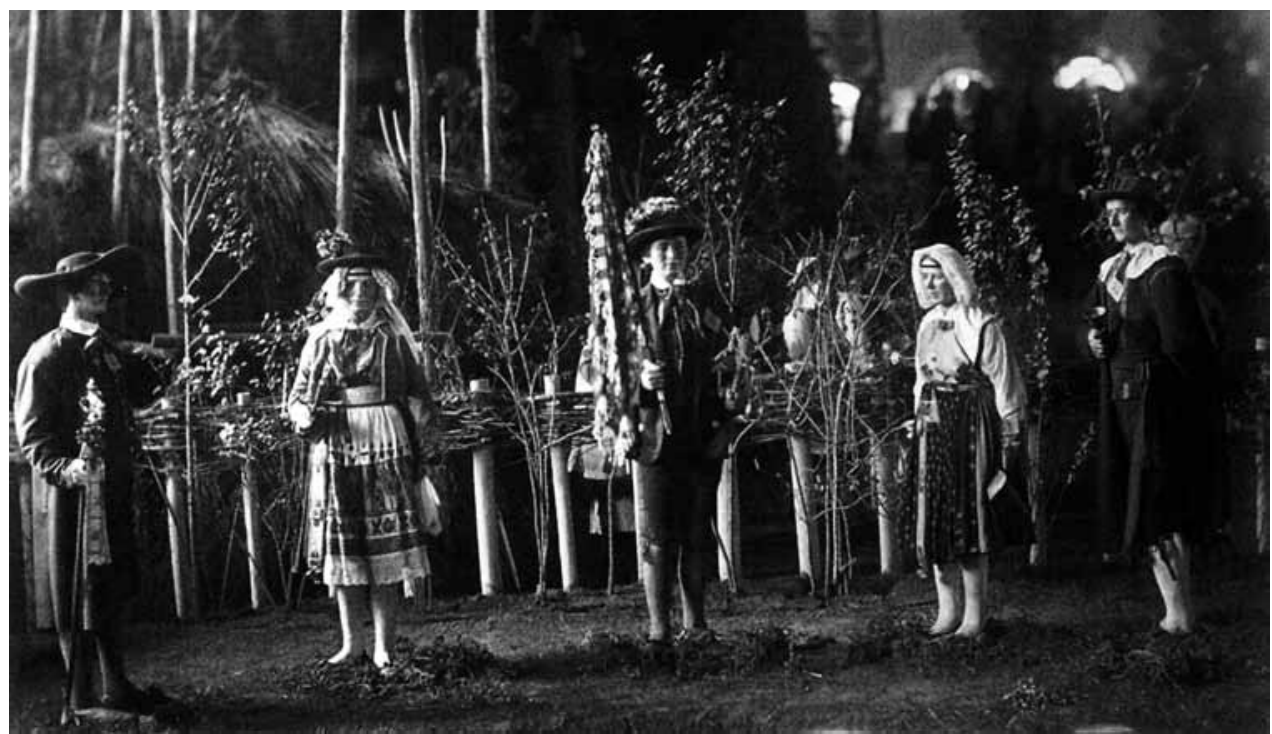

Slovenian nuptials in Zilja/Gail Valley, a photograph of the display at the Ethnographical exhibition in Moscow, 1867.

* Acknowledgement: All photographs are from the Russian Museum of Ethnography, Moscow. The author thanks Olga Karpova for her help and for permission to include the photographs in this article. 


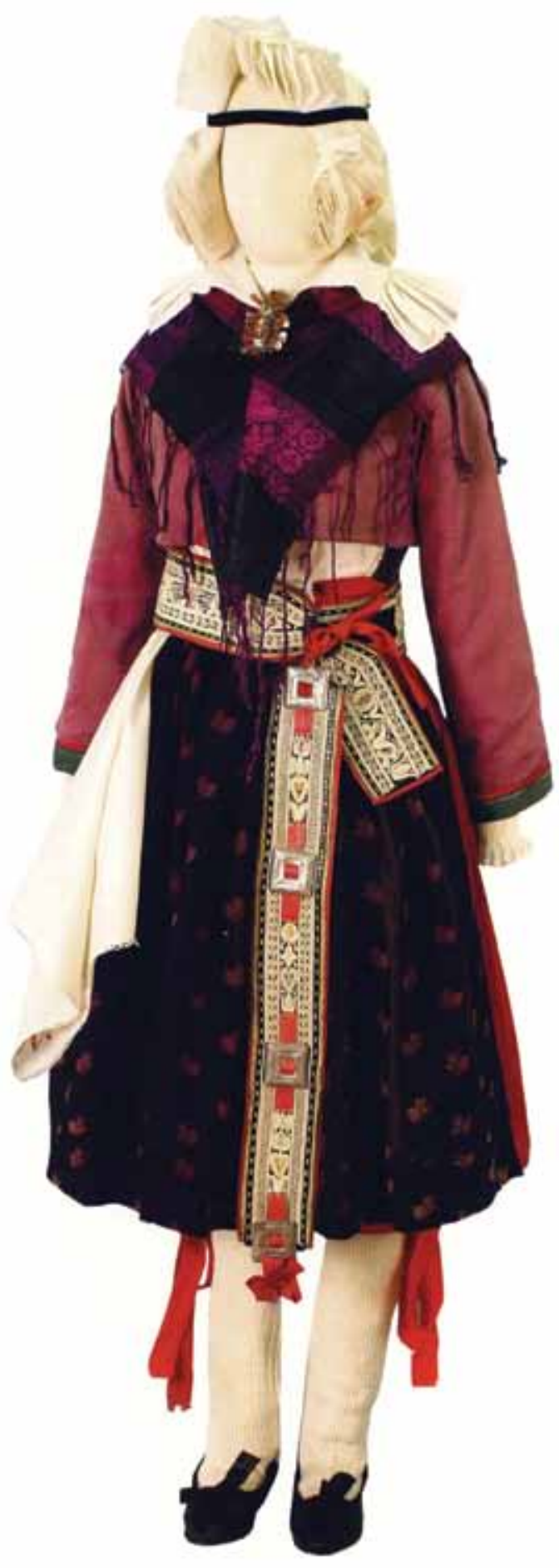

Bride costume, donated by Matija Majar.

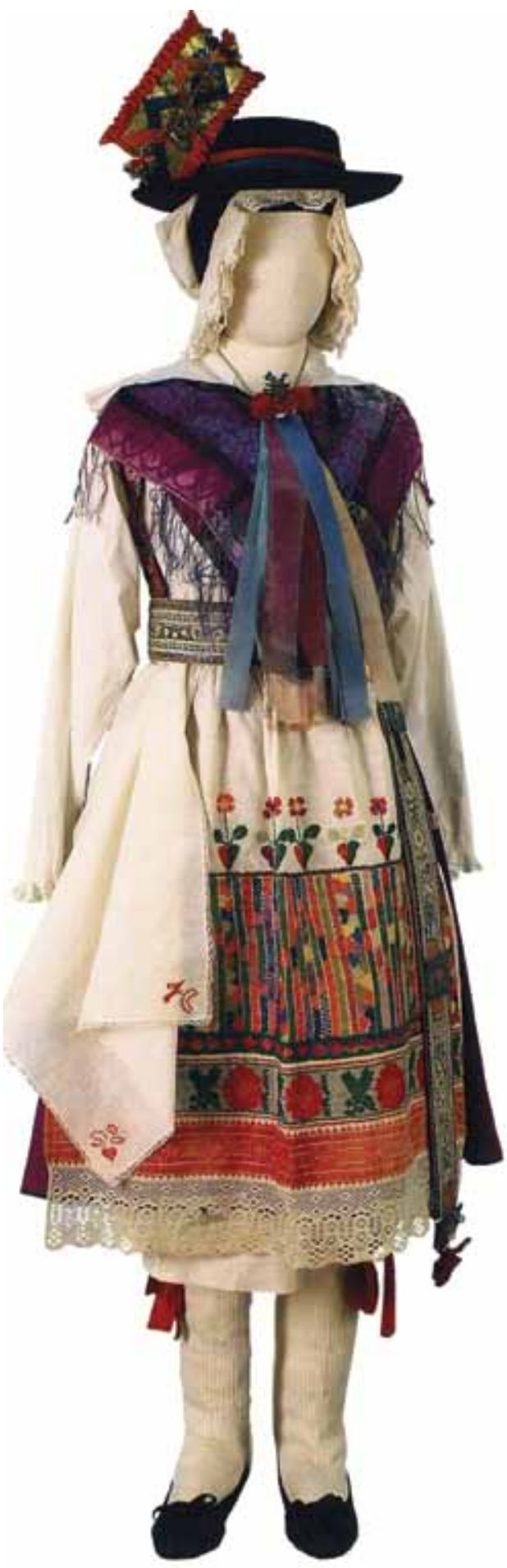

Bridesmaid costume, donated by Matija Majar. 


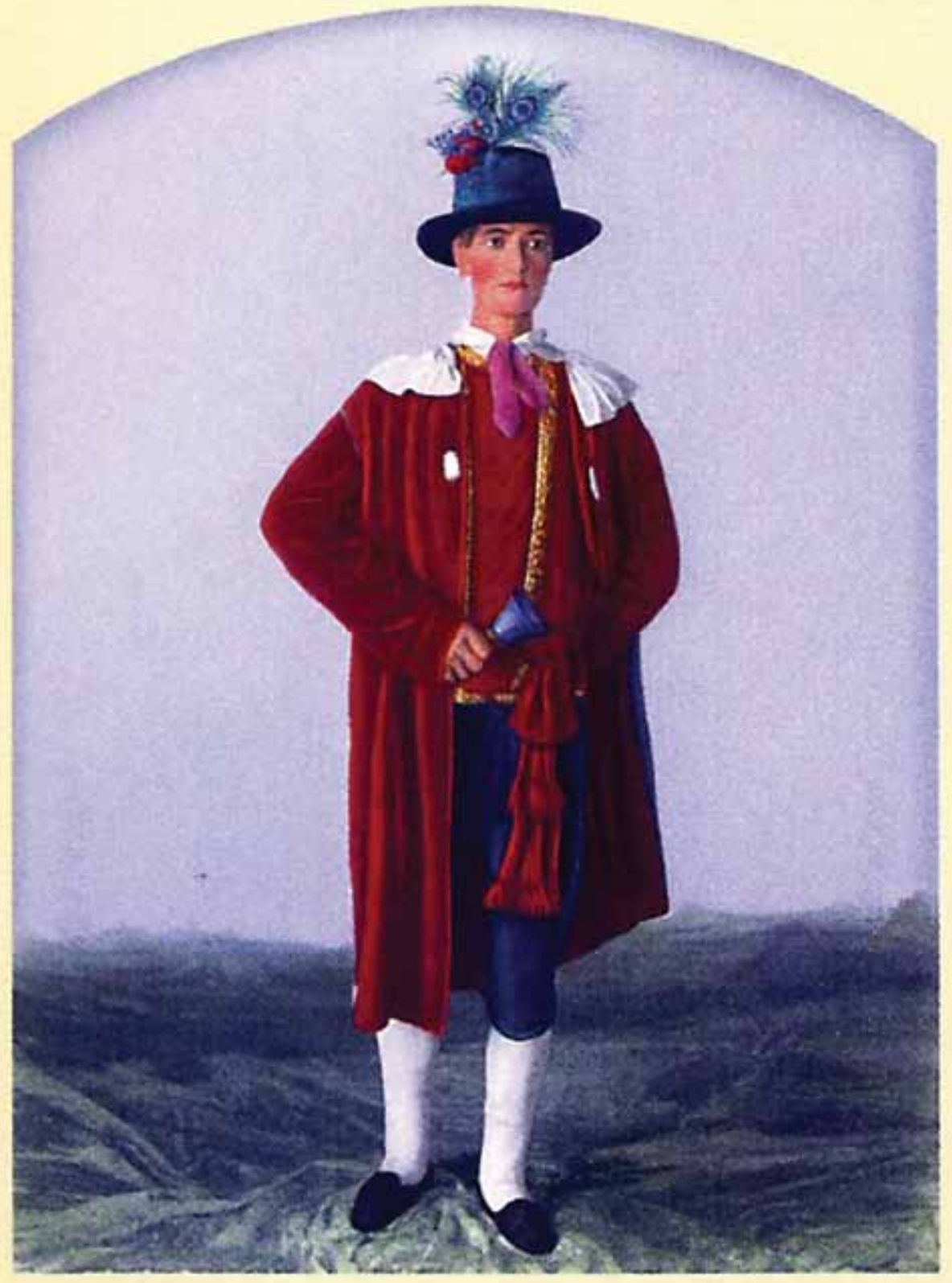

Bridegroom, photograph by T. A. Mitrejter, 1880 . 
Mikhail Katkov, writing in Moskovskiya vědomosti on 12 May 1867, recognized that in a collection with a scholarly aim there was "no place for peasants from the opera and peasant women from the ballet," and that it was a matter of course that the Bashkirs left their dirty linen at home to be washed, and showed up at the exhibition in clean shirts and in their Sunday best; the Czech, Croat, Montenegrin mannequins did just the same and dressed in their "Sunday best costumes, splendid and picturesque." But the Russians, Katov wrote, beat themselves on their heads to show themselves "in rags and tatters, and as repulsive as possible" (cited in Klaczko 1867: 22, 27). Katkov went on venting his frustration:

In the Great Russian group, which has to represent the very quintessence of the empire, we would look in vain for such signs of mysterious and moral strength that draws in and usurps neighboring tribes; we are filled with astonishment at the sight of these masses without a physiognomy, without an air, without sense. Why is there none - not a single beautiful and attractive face out of thirty specimens of women in the group! Nothing but big and stupid eyes put on the top; nothing but noses like potatoes, nothing but rudeness and ridiculousness! (cited in Klaczko 1867: 28)

The example of the ethnographic exhibition of 1867 highlights the complex dialogue inherent in the relationship between scholarship, society, and state. The apparent hijacking of the exhibition to serve as a vehicle for expressing Russian nationalism and Panslavism illustrates the difficulty of maintaining a position of scholarly isolation above the fray of contemporary political and ideological concerns. However, in adopting the vocabulary of scholarship as a tool of legitimization, purveyors of ideological agendas also assent to a range of constraints limiting the manner and extent to which these agendas can be articulated. Thus, scholarship in the hands of power, as Knight phrased it, "proved to be a two-edged sword" (Knight 2001: 28).

\section{MATIJA MAJAR'S GROUP}

Matija Majar donated Slovenian folk costumes from the Zilja-Gail Valley for the ethnographic exhibition. He also procured complete furniture for one room: a bed, a chest, a table and chairs, all painted with flowers, a blanket, and the cover for the bed all knitted with gay colors as used by Slovenians in the Zilja-Gail Valley. For folk costumes, he arranged wedding attire customary for the Zilja-Gail Valley: the groom, the bride, a bridesmaid, and the "standard-bearer." Before he sent the costumes, which cost over 350 gulden, not to mention his own efforts and troubles, he gave them to local people to do themselves and had them photographed in Villach (-ž-. 1893: 193). ${ }^{3}$

3 “These images are still circulating in the ethnographic books" (-̌̌z-. 1893: 193). 
The rich collection of wedding costumes and trousseaus impressed the organizers of the exhibition, and they decided to put on display a scene of a Slovenian wedding ritual with wax figures. In order to do this as authentically as possible, they needed photographs and drawings of typical representatives from the Zilja-Gail Valley. At Raevsky's behest, Majar fulfilled this task as well. He sent twelve photographs and a few drawings, representing six Slovenians (four men and two women), which served as models for the wax figures. In addition to costumes and photographs, Majar contributed an explanation to the group, a description which-according to Mikhail N. Speranski-is a comprehensive treatise about Slovenian manners and customs and the past, and partly also of other Slavic tribes (Čurkina 1974: 61; Kerimova 1998: 69). ${ }^{4}$

The Croatian visitor Petar Matković described how Majar's group was arranged at the exhibition:

Group ten comprises Slovenians from the Zilja-Gail Valley from the southwestern extremities of Slavic settlement, where the Slavic world meets with the German and Italian worlds. This group, one of the most interesting in the entire exhibition, represents a wedding scene from Slovenian life, and an ancient custom: smashing a barrel in a quintain competition and competing for a wreath. The whole group was placed inside the courtyard, girdled around with a fence. Here belongs also the bed for the wedded couple and the bride's trousseau. For this scene, the Priest Matija Majar deserved great merit. The group consisted of six statues (32 to 37): a Slovenian bride, a Slovenian groom holding a cup of wine in his right hand, and in his left the so-called tine with a bunch in which there are two apples and two clubs, which could be said to be a symbol from the pre-Christian era; and two Slovenian married men and a Slovenian bridesmaid, and finally two Slovenian riders (37), holding a bridle in the left hand, an iron pole in the right preparing to deliver a heavy blow to the barrel. The entire game has an allegorical association with wedding customs. The last image is the best masterwork of all by the artist Zakrevsky. (Matković 1867: 207)

4 Speranski emphasized that "Majar's treatise on the life and customs of the Slovenians from the ZiljaGail Valley deserves recognition even today: we can fully rely on his conscientiously drawn and accurate observations; detailed findings on the spot, gathered by a man that carefully studied the life of his parishioners and was, moreover, close to the everyday life of simple people, can give us the right notion about the way of life of part of the Slovenians, although only within the framework of the objects collected for the exhibition." For Speranski, Majar as ethnographer was one of those "that deeply and sincerely respected their nation, but still had not emancipated themselves from romantic archaeological aspirations and had not yet mastered the strict scholarly methods of linguistics and comparative study of life and literature." According to Speranski, "Majar could be classified as a significant worker, a collector, if not a researcher” (cited in Čurkina 1974: 61). 
The Russian press dedicated much attention to Majar (Shchebalsky Karlovich 1867: 25; Curkina 1974: 61). The book The All-Russian Ethnographic Exhibition and the Slavic Congress in May 1867, published in 1867 in Moscow, portraying Slavic guests and their stay in Russia, assigned more space to Majar's biography than to the biographies of Palacký and Rieger combined. In the biography, contributed by Popov (Komitet vystavki 1867: 135-139), Majar is portrayed as one of the most active harbingers of Slavic mutuality and brotherhood of the South Slavs. The author also commended Majar's literary works, which "allots him a place of honor in the ranks of the South Slavic writers." The book further emphasized that in 1848 Majar produced the famous petition submitted to the emperor of Austria with the request for a United Slovenia, and it also highly valued Majar's work in compiling a Slavic grammar:

With this attempt, Majar has already significantly facilitated the mutual literary rapprochement of the Slavs. In this way, which was first proposed by Majar, it is possible with efforts of Slavic writers from various tribes to develop altogether organically active literary connections.

(Komitet vystavki 1867: 139)

For his valuable contribution Majar received one of the greatest awards at the exhibition: the bestowal of a second degree. ${ }^{5}$ He was also elected a collaborator of the Society of Friends of Natural History, Anthropology, and Ethnography (in Moscow), a member of the Society of Friends of Russian Literature (in Moscow), and a corresponding member of New Russia University (in Odessa) (Čurkina 1995: 88).

\section{THE POLITICS OF A SCHOLARLY EXHIBITION}

The ethnographic exhibition conceived as a scholarly event took on a completely different connotation with the change of plan in accordance with Popov's proposal. Then, the concept of the exhibition as a purely academic project of a learned society swelled into a public cause supported by the Panslavists; that is to say, a political project. The fact that the tsar opened the exhibition in person, even after the obviously nonscholarly interest that it had evoked at home and abroad, also indicates the government's interest in the affair (Petrovich 1956: 202). When the decision came to arrange the Slavic section, Bogdanov's original narrative centering around the anthropological diversity of the human race was eliminated as well. However, the new narrative implicit in the idea of a Slavic sector was fraught with symbolic implications. In the mid-nineteenth century, the inclusion of the Slavic peoples of eastern Europe into an all-Russian exhibition inevitably created the impression that the Slavs should ultimately be integrated, at the very least culturally and perhaps even politically, into the

5 Awards of the first degree were awarded exclusively to persons of princely classes, with the exception of Raevsky (Čurkina 1974: 61). 
Russian Empire (Knight 2001: 17). Although the organizers attempted to sidestep the political implications of the Slavic participation by emphasizing the strictly scholarly principles and goals behind the exhibition, their plans raised serious doubts, especially in the Habsburg Empire. The decision to invite a large delegation of prominent Slavic scholars and politicians to Moscow to view the exhibition accentuated even more the political resonance of the event (Knight 2001: 18).

The Moscow Ethnographic Exhibition coincided with a political crisis in Austria. In the context of this political crisis in the Austrian Empire, the contribution of ethnographic objects for the Moscow exhibition gained the character of a political demonstration, when, in April 1867, the Austrian government sought to undergo a radical administrative change towards a new understanding with the Hungarians. The ensuing proclamation of dualism divided the empire into two sections: Franz Joseph I ruled in both, holding the title of emperor in the western Austrian lands, and king in the Kingdom of Hungary. The implication of this new empowerment of Hungary was perceived as detrimental for the Slavic plurality under Austrian rule. Within this context, the Ethnographic Exhibit and the Slavic Congress acquired a special meaning for the West and South Slavs. In Prague, the organ of the Young Czech Party, Narodni Listy, openly recognized the newly acquired political character of the planned participation at the Moscow exhibition and congress, stating:

We do not intend to conceal the fact that the Moscow Exhibition bears a truly profound political significance for those of us that are not going for the sake of mere philology or ethnography. It is not we that have lent it this significance. Those that inaugurated dualism in Austria, which endangers the independence of the Czech crown and the Czech nation with it, have transformed a simple ethnographic exhibition into a Slavic Congress with an undeniable political significance.... The Slavs of all lands are going there not "to flirt with a distant state in the East" but to greet a people close to them by blood and kinship, and to establish a foundation for the reciprocity of all the Slavic stock, which will procure protection especially for the Austrian Slavs against all kind of future storms that threaten that national development they so vainly seek here at home. (cited in Komitet vystavki 1867: 102)

Such were the sentiments not only of the Young Czechs but also of the Slovaks, Serbs, Croats, Slovenians, and Ruthenians of the Austrian Empire. It was no accident that, less than two weeks after Emperor Franz Josef I had been crowned king of Hungary under the terms of the compromise (Ausgleich), sixty-three of his Slavic subjects set off to Moscow to seek solace. They went, as Rieger made clear, "to demonstrate, not to conspire” (Prelog 1931: 37; Tobolka 1933: 154; Petrovich 1956: 205).

That public interest in the Ethnographic Exhibition in Moscow had been greatly stimulated by the visit of the Slavic guests and of the 83,048 exhibition-goers. On the 
occasion of the Slavs' departure from Russia, Vladimir Lamansky commented: "the Slavic question has left the books and cabinet chambers and has gone out into the streets, the squares, the churches, and the theaters; this question has now become allRussian, all-European" (Komitet vystavki 1867: 459).

After the ethnographic exhibition closed on 18 June 1867, the exhibits were put into a special department of the Rumyantsev Museum, named the Dashkov Ethnographic Museum (Matković 1867: 214; N. Z. 1867: 177; Knight 2001: 25; see also Urban 1977: 239). ${ }^{6}$ Geographical determinism was the primary model through which to explain the differing levels of culture among the peoples of the Russian Empire. A certain N. Z. described the exhibition in the ethnographic museum as follows:

The exhibition is well made. Highlanders stand on artificial mountains, Lowlanders stand surrounded with plants that grow in their native country; domestic animals, houses, and tents are also to be seen. Everything is arranged in a way that puts before the eyes of a visitor a really good representation of Russia and the neighboring Slavic lands. Special credit that the physiognomies of the peoples are very characteristically sculptured is due to Mr. [Nikolai] Ramazanov, professor at the Moscow School of Arts, with his students.

The northern peoples are on the side of the entrance, and the southern ones on the opposite side. In the middle, on the side in the direction of the university, is the imperial lodge and opposite it on a suitable plain the fair, where all the peoples of Russia are to be seen. Between this central and utmost end are set the other Asiatic and European people in diverse groups.

All figures on display are of full human size and belong-according to the catalogue - to three main sections: non-Slavs, East Slavs, and West Slavs. Of the first there are 114, of the second as many, and of the third only 63. This is the main part of the exhibition. Close to this, in one separate building behind the Caucasus, one may see a rich collection of costumes, of which there are 155; behind the Montenegrin mountains is the craniological section with many skulls of the first settlers of the place on which Moscow now stands. In another section there are household requisites and tools of various peoples, and also musical instruments. Then a special collection of models of characteristic buildings and tools are displayed. There is also a collection of excellently made and interesting photographs and drawings. (N. Z. 1867: 177)

6 The Dashkov Ethnographic Museum apparently continued to function up until the 1930s, when its contents were transferred to the Museum of the Peoples of the USSR. Eventually the collection was moved to the State Museum of Ethnography of the Peoples of the USSR in Leningrad (Knight 2001: 12-13). 
Slovenian ethnographic objects on display in a Moscow public museum were a powerful attraction for Slovenian travelers visiting the capital of the powerful Slavic empire in the early twentieth century (Aškerc 1903: 532; Vošnjak 1906: 223; Marn 1911: 1; Knific 1914: 393-394). Anton Aškerc, who made his journey to Russia "as a conscious Slav" (1903: 474), was thrilled when he saw the Slovenian ethnographic objects displayed:

Very important is the historical museum, an imposing new building, where you find historical, ethnographic, and archaeological collections from across immense Russia. Here there are also costumes of all the Slavic tribes in Europe. We Slovenians are represented, too! Namely, in a glass cabinet there stands a life-sized group of Slovenian wedding guests from Carinthia. An inscription on the cabinet states: "A gift from Matija Majar."(Aškerc 1903: 532)

\section{THE SLAVIC CONGRESS}

The Slavic Congress in Moscow was in fact no congress in any formal sense of the term. Indeed, the designation $s^{\prime \prime} e z d$ 'congress' was employed throughout by its participants in its simple generic meaning of 'get-together' (Petrovich 1956: 207), under František Palackýs motto svưj $k$ svému 'each to his own' (Komitet vystavki 1867: 106, 335). However, it was not just an "ethnographic episode," as Russian officials were describing it, either (Tanty 1970: 190); it had become a European affair long before its actual convocation. The German press in Austria saw the meeting as a poorly concealed political demonstration and propaganda effort to consummate a union between the West and South Slavs and Russia; it advocated stiff prosecution of the Slavic guests after their return home (Mijatovich 1885: 3).

Not so the Russian press, which, on the contrary, endeavored to prove its apolitical character (Nikitin 1960: 202). Mikhail Pogodin, for instance, wrote in Moskovskiya védomosti on 13 and 22 May 1868: "Russia does not need any expansion of its territory, which is already boundlessly vast, and also not any increase of its population, which is by now growing more rapidly than anywhere else" (cited in Nikitin 1960: 203). The Russian hosts, too, avoided talking about politics. The result was an anomalous situation:

The Russians, who were suspected by all of Europe for their imperialistic designs on the Slavic peoples, were carefully sidestepping political issues. The visiting Slavs, however, were bitterly disappointed. Most of them had come to Russia precisely with the aim of scaring Vienna into compromise by consorting with bogeys. Their strategy was doomed to failure if Russia was going to insist on being such a cautious and prim bogey! (Petrovich 1956: 217-218) 
At the Slavic Congress, the delegates heard lectures by members of the Academy of Sciences, and by spokesmen of eighteen learned societies. Among the various topics discussed, the proposition of Slavic reciprocity and cultural collaboration held special interest. When Ivan Aksakov summarized the achievements of the Slavic Congress of 1867 in early 1868, he could enumerate much:

There was no political program established, no course of action agreed upon, no political advice or instructions given. No Russian said anything or thought to incite the Slavic guests to insubordination against their governments. There was never expressed any intention or even suggestion of Russia's absorbing the Slavs, nor even of the political unification of the Slavic peoples under Russia's leadership. There was expressed only this: our joy on meeting, the happiness of becoming acquainted with our brethren ... and a sincere warm desire that all the Slavic peoples might secure life, liberty, and an independent development. (cited in Petrovich 1956: 234-235)

A topic that was in fact talked about at the Moscow Congress was the role that the Russian language should play a role in Slavic mutuality. In Saint Petersburg the tsar himself encouraged his guests to learn Russian. Minister of Education Dmitry Andreyevich Tolstoy stated that the "Russian language and Slavic languages are one language" (Klaczko 1867: 65-66).

The suggestion did not find approval among the majority of delegates from other Slavic countries. Vladan Djordjević, a Serbian delegate at the Moscow Congress, opposed the introduction of Russian as the standard language of all Slavs, as well as the elimination of any other national languages. He emphasized his peoples' desire to partake equally in the benefits of European civilization (Milojković-Djurić 1994: 82). A similar view concerning national languages was declared by the Czech delegate František Rieger. The Slavic languages were once so close to one another that the various Slavic peoples might have developed a single tongue and a single nationhood, but historical development had willed it otherwise. Rieger also spoke about the importance of independent cultural development and stressed the need for Slavic cultural collaboration and reciprocity (Petrovich 1956: 225; Milojković-Djurić 1994: 82-83).

Matija Majar was one of the few that supported the idea (Tanty 1970: 128). As Majar explained in his Slavjan, quoting the historian Pogodin and using a "mutual Slavic language":

The Slavs of all tribes have seen each other for the first time when they came together, and this happened in Moscow, which received them in a brotherly manner, embracing them openheartedly, sincerely, and vigorously. All classes of people hustled and thronged to show their feelings. Here there were Serbs, Bulgarians, Czechs, Moravians, Galicians, Slovaks, Slovenians, Kashubians, Croats, Bosniaks, Montenegrins, Lu- 
satian Sorbs, and Russians. Here there were the Orthodox, Catholics, Eastern Catholics, and Protestants. They all felt like brothers, of one root, they felt like one nation divided into different tribes - with one language divided into different dialects. They all felt that they all belonged to one body, to one blood, and it showed to all the natural idea of unity.

Language was revealed as the first uniting factor; the language is common to all Slavs, but the dialects are different; we are settled in far distant lands and in some places our dialects grow up hardly intelligible to one another; however, in general it is easy to learn any one of them. Indeed, in actual fact, if the Slavs - the Czechs, Croats, Serbs, Slovenians, and the rest — can learn the foreign language of German perfectly; if all the Turkish Slavs_Serbs, Bulgarians, Bosniaks, and Herzegovinians—speak Turkish and Greek, it is for all of them incomparably easier to learn any one of the Slavic dialects, which are all related, closely linked, and cognate dialects.

All this was self-evident to all; and to the question of which dialect should be selected as a means of mutual communication, one and the same answer showed to all. The Russian dialect-because it belongs to a nation of fifty million souls; - because it rules in a country comprising eighty million inhabitants, - because, in the firm persuasion of all connoisseurs it comprises in itself the greatest amount of characteristics that all other particular Slavic dialects have together, and, last but not least, because it is the heir and successor to the Church (Old Slavic) language. (Majar 1873a: 102-103)

Majar, a native of a Carinthian village close to the linguistic border between Slovenian and German, ardently supported the idea of a "mutual Slavic language." He himself presented his views on the need for Slavic mutuality in one of his articles, quoting the words of Jan Kollár from his book Hlasové o potrebè jednoty spisovného jazyka pro Čechy, Moravany a Slováky (A Voice for the Need for a Common Standard Language for the Czechs, Moravians, and Slovaks):

Out of the Slovaks will be nothing, out of the Czechs and Moravians also nothing - sorrowful heart have we, the Yugoslavs, to add: out of the Slovenians, Croats, Serbs, and Bulgarians will be nothing as well-if they remain fragmented; but if they unite, if they stick together, stay together: they will heroically defend themselves from all the enemies attacking their language and nationality (Majar 1873c: 138; see also Komitet vystavki 1867: 138; Fikfak 2008: 39).

Although he supported equal status for the Slavs in Austria-Hungary and the Ottoman Empire, Majar did not apply this opinion to non-Slavic peoples. Because he saw Russia 
as the main instrument for realizing his ideas and because he formed his opinion about it merely based on the Ethnographic Exhibition and the Slavic Congress, he excused Russian imperialistic policy and defended its role in Asia as a mission civilisatrice (Majar 1873b: 113).

The Ethnographic Exhibition and the Slavic Congress stand out as a definite phase in the history of Panslavic thought. In itself the idea of the exhibition and the congress was an attempt to rationalize Panslavism on a scholarly basis, as unity based on race and blood rather than on religious sentiments. The whole event was just "Words, words, words instead of swords, swords, swords," as the Serbian participant Laza Kostić declared in English (Komitet vystavki 1867: 227; Fadner 1962: 276-277). Nevertheless, it represented a significant manifestation of Slavic solidarity, of importance in later endeavors of West and South Slavs for their national emancipation.

The All-Russian Ethnographic Exhibition, the first of its kind, set an important milestone in the history of Russian anthropology and ethnology, and made an impact on the development of the discipline elsewhere (Matković 1867: 191, 214; see also Urban 1977: 239). It exerted an impact on the consciousness of importance of cultural heritage for identity with all Slavic peoples. In view of this, in his political sermons France Jaroslav Štrukelj called upon his Slovenian compatriots: "Let's say what the Slavs said of the exhibition in Moscow: 'We won't give away a single shack to the foreigners anymore!” (Jaroslav 1872: 63).

The exhibition in Moscow in 1867 was a timely occasion to show the world not only that the Slovenians are not a tiny nation, but a member of a huge Slavic family. This notion was of no lesser importance in the decades to come, in which the Slovenians' national identity was frequently put under pressure by their mightier neighbors. As Bogumil Vošnjak put it in his Russian studies in the early twentieth century: "Invaluable and indescribably joyful is the knowledge that the Russian nation is akin to us by blood, spirit, and language" (Vošnjak 1906: 21).

On the other hand, however, the all-Slavic Ethnographic Exhibition in Moscow served as an opportunity to "scientifically" prove the existence of the Slovenian nation and its particular culture, which was, as yet, not so self-evident. This was confirmed by the very fact that the exhibits donated by Matija Majar and others were designated by their ethnonym, and not by their provenance (Carinthia, Carniola, etc.), which was, back then, still a standard practice in their homeland. The importance of being represented by ethnonym reveals the true nature of the discipline of ethnography: the act of naming a nation is a political act par excellence. This is why the Russian organizers "forgot" the Polish name and replaced it with less "pretentious" geographic names. As a consequence, by taking part in the exhibition in Moscow under their national name, the Slovenians showed the world that they had a culture that was not only worth displaying at the exhibition where all the Slavic nations competed, but also that their culture differed from other Slavic cultures. Within this 
context, the Slovenian exhibits on display in the Ethnographic Exhibition played a part in the process of creating Slovenian national identity, and Slovenian national awakeners loved to make their pilgrimage to Moscow to see the exhibits even in the early twentieth century.

The contemporary Slovenian press was well aware of the importance of the name, and it vigorously defended the decision to take part in the event against the attacks from the German politicians and press. Along these lines, Novice gospodarske, obrtniške in narodne, in its polemics with the Laibacher Zeitung, asked the following question:

Why did it not add any appendix, when exhibits were sent from Ljubljana to a French or English exhibition and our participants also won medals there? Indeed, if such a spirit was blowing in all hearts as with the contributors to the Laib. Zeit., neither Paris, nor London or Moscow, knew what the Carniolans have, what they can show the world. (Anon. 1867k: 358)

The world-as-exhibition showing different peoples and their culture was a manifestation of the superiority and imperialism of host nations. The imperial powers used exhibitions to send the message that progress and civilization could only occur within the colonial enterprise (see, e.g., Yengoyan 1994: 75). For them, the motto of exhibitions was: scholarship is a proof of our superiority. For smaller nations, especially for "awakening" ones, taking part in an international exhibition was a convenient opportunity to establish themselves as nations. In their interpretation, the meaning of such exhibitions was not the same: they were expressions of nationalism, and their motto was: scholarship is proof of our ethnic individuality. However, the main aim for all was political, not scholarly.

\section{REFERENCES}

Anonymous

1866a Etnografična (narodopisna) razstava v Moskvi na Ruskem. Novice gospodarske, obrtniške in narodne, 239-240, 256-257, 305-306, 312, 338.

1866b Narodopisna razstava v Moskvi. Slovenski glasnik, 1 November, 415.

1867a Besuch der ethnographischen Ausstellung in Moskau. Die Debatte, 25 April, 1.

1867b Keine Pilgerreise nach Moskau. Die Debatte, 26 April, 2.

1867c Panslavistischer Vergnügungszug nach Moskau. Die Presse, 26 April, 2.

1867d V Moskvo. Novice gospodarske, obrtniške in narodne, 1 May, 149-150.

$1867 \mathrm{e}$ Iz Ljubljane. Novice gospodarke, obrtniške in narodne, 1 May, 148-150.

$1867 \mathrm{f}$ Zur Moskauer Ausstellung. Die Debatte, 4 May, 2.

1867g Ein polnischer Absagebrief an die Czechen. Laibacher Zeitung, 10 May, 1.

1867h Popotovanje Slovanov v Moskvo I. Slovenski gospodar, 1 June, 4.

1867i Panslavistisches. Laibacher Zeitung, 27 June, 1-2.

1867j Novičar. Slovenski gospodar, 25 July, 4.

$1867 \mathrm{k}$ Iz Ljubljane. Novice gospodarske, obrtniške in narodne, 23 October, 356-358.

1885 Slovenci v zlati Pragi. Slovenec, 22 August, 3. 
Aškerc, Anton

1903 Dva izleta na Rusko: Črtice s potovanja. Ljubljanski zvon, 473-483, 527-540, 586-599, 651$665,714-730$.

Bennett, Tony

1995 The Birth of the Museum: History, Theory, Politics. London: Routledge.

Bleiweis, Janez

1844 Popis obertniske razstave v Ljubljani. Kmetijske in rokodélske Novize, 9 October, 162-163.

Bond, George C., and Angela Gilliam

1994 Social Construction of the Past: Representation as Power. London: Routledge.

Clementis, Vladimir

1943 “Panslavism." Past and Present. London: Williams, Lea \& Co.

Čurkina, Iskra V.

1974 Matija Majar Ziljski. Ljubljana: Slovenska akademija znanosti in umetnosti.

1995 Rusko-slovenski kulturni stiki od konca 18. stoletja do leta 1914. Ljubljana: Slovenska matica.

Fadner, Frank

1962 Seventy Years of Pan-Slavism in Russia: Karazin to Danilevskiu, 1800-1870. Washington, DC: Georgetown University Press.

Fikfak, Jurij

2008 Matija Majar and Ethnography. In: Bojana Rogelj Škafar (ed.), Razstava Slovani Evrope = The Exhibition The Slavs of Europe: slovenski prispevek $=$ the Slovene contribution. Loka pri Mengšu: Forum slovanskih kultur, 29-43.

Greenhalgh, Paul

1988 Ephemeral Vistas: The Expositions Universelles, Great Exhibitions and World's Fairs, 1851-1939. Manchester: Manchester University Press.

Hlavačka, Milan

2006 Ještě jednou pout' Slovanů do Ruska v roce 1867. In: Zdeněk Hojda, Marta Ottlová, and Roman Prahl (eds.), "Slavme slavnè slávu Slávóv slavných": Slovanství a česká kultura 19. století. Prague: KLP - Konisch Latin Press, 38-55.

Jaroslav, Fr.

1872 Politične pridige. Novice gospodarske, obrtniške in narodne, 21 February, 62-63.

K. M.

1867 Iz Celovca. Slovenski glasnik, 15 March, 95.

Karasev, V. G., S. A. Nikitin, N. Petrovich, and I. V. Churkina (eds.)

1975 Zarubezhnie Slavyane i Rossiya: Dokumenti arhiva M. F. Raevskogo, 40-80 godi XIX veka. Moscow: Nauka.

Karpova, Olga

1975 Zarubezhnye slavyane. In: N. M. Kalashnikova (ed.), Slavyane Evropy i narody Rossii: K 140-letiyu pervoy etnograficheskoy vystavki 1867 goda. Saint Petersburg: Slavija, 234-254.

Kazbunda, Karel

1924 Pout Čechủ do Moskvy 1867 a rakouská diplomacie. Prague: Orbis.

Kerimova, Mariam M.

1998 Slovenija in Slovenci v delih Alekseja N. Haruzina in Vere N. Haruzin. Kronika 1-2: 66-82.

Klaczko, Julian

1867 Kongres moskiewski i panslawistyczna propaganda. Kraków: Czas. 
Knific, Ivan

1914 Matuška Rusija. Dom in Svet, 389-396.

Knight, Nathaniel

2001 The Empire on Display: Ethnographic Exhibition and the Conceptualization of Human Diversity in Postemancipation Russia. Washington, DC: The National Council for Eurasian and East European Research.

Komitet vystavki

1867 Vserossiyskaya etnograficheskaya vystavka i slavyanskiy s"ězd v maè 1867 goda. Moscow: V Universitetskoy Tipografii (Katkov i Ko).

Majar, Matija

1873a S"ězd. Slavjan 7, 97-103.

1873b. Cirilica, latinica i asijski jeziki. Slavjan 8, 113-115.

1873c Prostor! - Slavjan! Slavjan 9, 138-140.

Majciger, Janez, Maks Pleteršnik, and Božidar Raić

1873 Slovanstvo. Prvi del: Občni pregled-Jugoslovani: Slovenci, Hrvati in Srbi. Bolgari. Ljubljana: Matica Slovenska.

Marn, R.

1911 Na Volgi. Slovenski narod, 29 December, 1.

Matković, Petar

1867 Moskovska etnografička izložba u svibnju 1867. In: Rad Jugoslavenske akademije znanosti i umjetnosti, Vol. I. Zagreb, 189-214.

Mijatovich, Elodie L., Mme.

1885 Panslavism: Its Rise and Decline. (Reprinted from the Fortnightly Review, 79, July, 1873.) London: Arliss Andrews.

Milićević, M. Đ.

1885 Etnografska izložba i Slovenski sastanak u Moskvi 1867 godine. Godišnjica Nikole Čupića, Vol. 7 , $1-87$.

Milojković-Djurić, Jelena

1994 Panslavism and National Identity in Russia and the Balkans 1830-1880: Images of the Self and Others. New York: Columbia University Press.

Mitchell, Timothy

1988 Colonising Egypt. Cambridge: Cambridge University Press.

N. Z.

1867 Razstava v Moskvi. Novice gospodarske, obrtniške in narodne, 5 June, 177, 185-186.

Nikitin, Sergey Aleksandrovich

1960 Slavyanskie komitety v Rossii v 1858-1876 godakh. Moscow: Izdatel'stvo Moskovskogo univerziteta.

Petrović, Nikola (ed.)

1989 Jugosloveni i Rusija: Dokumenti iz arhiva M. F. Rajevskog 40-80 godine XIX veka. Vol. II, Book 1. Belgrade: Istorijski institut Beograd; Institut za slavistiku i balkanologiju Akademije nauka SSSR.

Petrovich, Michael Boro

1956 The Emergence of Russian Panslavism 1856-1870. New York: Columbia University Press.

Picht, Ulrich

1969 M. P. Pogodin und die Slavische Frage. Ein Beitrag zur Geschichte des Panslavismus. Stuttgart: Ernst Klett Verlag. 
Polit-Desančić, Mihailo

1883 Sve dosadanje besede dra Mih. Polita-Desančića sa povesničkim crtama iz srpske političke borbe od god. 1861-1883. Novi Sad: Parna štamparija Nikole Dimitrijevića.

Prelog, Milan

1931 Pout'Slovanů do Moskvy roku 1867. Prague: Orbis.

Prijatelj Ivan

1938-1940 Kulturna in politična zgodovina Slovencev 1848-1895. Ljubljana: Akademska založba.

Rydell, Robert W.

1984 All the World's a Fair: Visions of Empire at American International Expositions, 1876-1916. Chicago: University of Chicago Press.

Shchebalsky Karlovich, Petr

1867 Moskovskaya etnograficheskaya vystavka. Wystawa Etnograficzna w Moskwie. Perepechatano iz Moskovskih Védomostey, v oboikh Varshavskih Dnevnikah. Warsaw.

Sk. Kh.

1867 Iz Petrograda; Novice gospodarske, obrtniške in narodne, 5 June, 186-187.

Slovenec cestujuči v Moskvu

1867 Čez Dunaj v Moskvo. Novice gospodarske, obrtniške in narodne, 22 May, 171.

Stelè, France

1934 Likovna umetnost v 1. 1933. Dom in svet, 181-198.

Tanty, Mieczysław

1970 Panslawizm, carat, Polacy. Zjazd Stowiański w Moskwie 1867 roku. Warsaw: Państwowe Wydawnictwo Naukowe.

Tobolka, Zdeněk

1933 Politické dèjiny československého národa od r. 1848 až do dnešní doby. Vol. II. (1860-1879). Prague: Nákladem "Českoslovénskeho kompasu."

Urban, Zdeněk

1977 Národopisná výstava v Moskvě v roce 1867 a ideový svět Jana Nerudy. Český lid 4: 239-240.

V. V.

1867 Pout'Slovanů do Ruska roku 1867 a její význam. Prague: Tiskem a nákladem dra Edv. Grégra.

Vošnjak, Bogumil

1906 Na razsvitu: Ruske študije. Ljubljana: L. Schwentner.

Vošnjak, Josip

1868 Govor posl. dr. Vošnjaka v dež. zboru štirskem proti adresi. Slovenski Narod, 19 September, 1-2.

1905 Spomini. (Prvi zvezek. Prvi in drugi del 1840 do 1867. l.) Ljubljana: Slovenska matica.

Yengoyan, Aram A.

1994 Culture, Ideology and World's Fairs: Colonizers and Colonized in Comparative Perspectives. In:

Robert W. Rydell and Nancy Gwinn (eds.) Fair Representations. World's Fair and the Modern World. Amsterdam. VU University Press, 62-83.

-̌̌- (= Jožef Rozman)

1893 Matija Majar Ziljski. Dom in svet, 193-203, 241-247, 289-296. 
Leta 1864 so na Univerzi v Moskvi ustanovili Društvo ljubiteljev naravoslovja (Obščestvo Ljubitelej Estestvoznavija), katerega člani so podprli zamisel o vseruski antropoloski in etnografski razstavi. Zoolog Anatolij Bogdanov je dobil zamisel za ta projekt, ko si je ogledoval Kristalno palačo v londonskem Sydenhamu, kamor so prestavili eksponate po zaprtju razstave leta 1851. Tudi Nil Popov je leta 1863 in 1864 po potovanju po slovanskih deželah Vzhodne Evrope ugotovil, da bi bilo dobro pripraviti razstavo, na kateri bi bili na ogled predmeti, povezani z etnografijo Slovanov. To naj bi bilo namreč po eni strani izhodišce za primerjalno raziskavo ruskih narodov, po drugi strani pa bi predstavili tudi slovanska ljudstva v Avstrijskem in Osmanskem cesarstvu.

Organizacijski odbor je $k$ sodelovanju pri pripravi razstave povabil tudi Slovensko matico s sedežem v Ljubljani. Janez Bleiweis, Lovro Toman in nekateri drugi so sodelovanje zavrnili, medtem ko je katoliski duhovnik Matija Majar sklenil sodelovati in je v Moskvo poslal popolno poročno opravo za šest ljudi iz Ziljske doline na Koroškem. Bogata donacija poročnih oblačil in pripomočkov je spodbudila prireditelje razstave, da so z voščenimi lutkami uprizorili poročni ritual. Da bi dogodek uprizorili čim bolj avtentično, so potrebovali fotografije in risbe značlnih slovenskih likov. Majar je v Moskvo zato poslal še dvanajst fotografij in šest risb (podobe štirih moških in dveh žensk), priložil pa je še pisno razlago dogodka, ki naj bi ga uprizorili.

Na moskovski razstavi so predstavili 116 lutk, oblečenih $v$ narodne noše neslovanskih ljudstev $v$ Rusiji, 118 lutk narodnih tipov vzhodnoslovanskih ljudstev in 66 lutk, ki so upodabljale zahodno- in južnoslovanska ljudstva. Vseruska etnografska razstava je bila tri mesece na ogled $v$ osrednji moskovski razstavni dvorani (t. i. Maneži). Sestavljena je bila iz treh delov. V prvem so si obiskovalci lahko ogledali različna ljudstva iz Rusije in drugih slovanskih dežel; ta so bila razdeljena $v$ dve skupini: $v$ neslovanska in slovanska ljudstva. Slednja so se nadalje delila na Vzhodne Slovane ter na Zahodne in Južne Slovane. Drugi del je bil posvečen splošni etnografiji, tretji pa antropologiji. Različna ljudstva so na razstavi upodobili tako, da si je obiskovalec lahko ogledal "živo etnografsko karto Rusije in celotnega slovanstva". Vsaka voščna lutka je bila podrobno izdelana, deli njihovih oblačil in vsi pripadajoči predmeti pa so bili natančno označeni.

Takšno predstavljanje ljudstev in njihovih načinov življenja je povezano tudi s političnimi nameni. Tako so prireditelji, npr., sklenili, da na razstavi ne bodo uporabljali poljskih imen, ko so predstavili Zahodne Slovane: Poljake so nadomestili z manj "povezovalnimi" Mazurijci, Krakovljani, Podlesijci, Litovci, Samogitijci idr., sčimer so se ravnali po načelu "deli in vladaj". Poleg tega so "primitivna" ljudstva, med katera so uvrstili Jakute in Samojede, predstavili v njihovem "naravnem" okolju, sčimer so postavili "znanstvene" temelje predstav o barbarskem neevropskem svetu.

Etnografska razstava $v$ Moskvi je sovpadla tudi s politično krizo Avstrijskega cesarstva, 
zaradi česar so prispevki za razstavo pridobili značaj politične agitacije. Aprila 1867 je namreč avstrijska vlada skušala izvesti radikalne administrativne spremembe za nov sporazum z Madžari. Razglasitev t. i. dualizma je cesarstvo razdelila na dva dela. Obema enotama je vladal Franc Jožef I., ki je imel naziv cesarja zahodnih avstrijskih dežel, bil pa je tudi madžarski kralj. Nekateri so razumeli, da poudarjanje pomena Madžarske škodi slovanski pluralnosti pod avstrijsko vladavino. V tem kontekstu sta Etnografska razstava in Slovanski kongres pridobila poseben povezovalni značaj med Zahodnimi in Južnimi Slovani.

Razstava v Moskvi je pokazala še, da Slovenci niso le majhen narod, temveč del velike slovanske družine. To zavedanje ni bilo nič manj pomembno $v$ desetletjih, ki so sledila, saj je bila tedaj slovenska nacionalna identiteta mnogokrat pod pritiskom, ki so ga izvajali mogočni sosedje. Bogumil Vošnjak je v razpravah, ki so nastale v zgodnjem 20. stoletju, tako dejal: "Neprecenljivo in nepopisno veselo je spoznanje, da je ruski narod nam soroden po krvi, duhu in jeziku. "Sočasno pa je vseslovanska razstava v Moskvi pomenila tudi priložnost, da se "znanstveno" dokaže obstoj slovenskega naroda in njegove posebne kulture, kar tedaj še ni bilo samoumevno. To se je potrdilo z dejstvom, da so razstavne eksponate, ki jih je doniral Matija Majar in drugi, označili z njihovimi etnonimi, ne pa s poreklom (Koroška, Kranjska itn.), kar je bila stalna praksa v domovini. Pomen predstavljanja z etnonimi namreč poudari etnografijo kot znanost, poleg tega pa je že samo poimenovanje naroda politično dejanje par excellence. Slovenci so s sodelovanjem na razstavi svetu dokazali, da imajo lastno kulturo, ki jo je vredno predstaviti na prireditvi, na kateri so se med sabo "pomerili različni slovanski narodi. Pokazali pa so še, da se njihova kultura razlikuje od drugih slovanskih kultur. V tem kontekstu je slovenska predstavitev imela pomembno vlogo $v$ procesu ustvarjanja slovenske nacionalne identitete.

Razstava je torej manifestirala superiornost in imperializem gostiteljskega naroda. Imperialna država je uporabila razstavo, da bi razširila sporočilo o tem, da je kolonialni kontekst predpogoj za napredek in civilizacijo. Zanjo je bil moto razstave naslednji: Znanost dokazuje naše superiornosti. Za manǰ̌e narode, še posebej za tiste, ki so se "prebujali", pa je bilo sodelovanje na razstavi priložnost, da se opredelijo kot narodi. Po njihovi interpretaciji je pomen takšnih razstav nekoliko drugačen, saj so izraz nacionalizma, njihov moto pa je bil: Znanost dokazuje našo nacionalno samostojnost. Kakorkoli, glavni cilj razstave je bil v vsakem primeru bolj politične kakor znanstvene narave.

Prof. Dr. Božidar Jezernik, Department of Ethnology and Cultural Anthropology, Faculty of Arts, University of Ljubljana, Zavetiška 9, 1000 Ljubljana, Slovenia. bozidar.jezernik@ff.uni-lj.si 